\title{
La deconstrucción de las imágenes del Libertador en: Bolívar sinfonía tropikal (1980), de Diego Rísquez
}

\author{
Rafael Arreaza Scrocchi*
}

Bolivar sinfonía tropikal (Venezuela, 1980, 75 min.)

Dirección: Diego Rísquez

Guión: Diego Rísquez, Gastón Barbu

Fotografía: José Antonio Pantín

Edición: Ricardo Jabardo

Música: Alejandro Blanco Uribe

Sonido: Jaime Kovacs

Intérpretes: Temístocles López, Antonio Eduardo Dagnino, Carlos Castillo, Hugo Márquez, María Adelina Vera, Diego Rísquez.

Desde una perspectiva basada en la alucinación la historia del Bolívar de Rísquez es expuesta a través de una imagen muy particular que simula los últimos días de vida del Libertador como si se tratase de un flashback en el que Bolívar rememora todos los eventos más impactantes de su existencia. Diego Rísquez imagina una escena muy particular en la que Simón Bolívar aparece acostado en su lecho de muerte cubierto por sábanas blancas y con la bandera venezolana a sus pies, suponiendo así, la agonía del Libertador en una cama que pareciese levitar al percibir a su vez el impacto de las olas del mar Caribe y la tenaz brisa costeña. Este simbolismo, refleja la imagen del Libertador en el año de 1830, fecha en la cual Simón Bolívar fallece en Santa Marta, Colombia, un 17 de diciembre. Esta puesta en escena que propone Rísquez al representar al Libertador en su lecho de muerte, invita al espectador a utilizar la imaginación y la percepción para despejar la historia que transcurre en este film silente sustentado por una secuencia de eventos específicos que ocurrieron en la vida de Bolívar desde su niñez hasta su muerte. La película, elaborada en formato Súper 8, plasma en la pantalla imágenes alegóricas asimiladas de la iconografía bolivariana, de los lienzos de la emancipación y de la historiografía venezolana. Dichos sucesos son representados por Rísquez en un film que incita y motiva al cuestionamiento y a la digestión de una ráfaga de eventos muy particulares que emulan los hechos históricos que impactaron la vida

\footnotetext{
* Vrije Universiteit Brussel - VUB, Faculty of Arts and Philosophy, Department of Language and Literature, Centre for Literary and Intermedial Crossings. 1050 Ixelles, Belgium. E-mail: Rafael.Arreaza-Scrocchi@vub.be
} 
de Simón Bolívar. El objetivo principal de este escrito, es la deconstrucción de esta película contrastando las imágenes propuestas por Rísquez con la historiografía y el simbolismo nacional que existe detrás de cada una de estas imágenes representadas en la pantalla.

\section{La Tierra de Gracia}

El sonido de las olas empieza la película invitando al espectador a percibir el trópico del Caribe inmediatamente. La primera imagen que se muestra es una roca que recibe el rocío del impacto de las olas del mar. Con una toma panorámica en cámara lenta, se observan el océano, un palafito (vivienda indígena), un pelícano y una india jugando en la orilla de la playa con su hija. Ambas desnudas huyen ante el arribo de un barco español y un conquistador de barba tupida que arriba a la orilla vestido con un yelmo y con un arma larga la cual utiliza para destrozar una gama de frutas tropicales que se encuentran en la arena. El simbolismo se percibe rápidamente, se trata de la llegada de los españoles al territorio venezolano en el año de 1498, o como el mismo Cristóbal Colón la llamó en su tercer viaje, la Tierra de Gracia o mejor dicho Paraíso Terrenal. ${ }^{1}$ La conexión que propone Rísquez en este instante es la del momento del encuentro entre dos culturas: la indígena, arraigada en su tierra, y la española, la invasora que ha llegado destruyendo los frutos tropicales abandonados por los indios luego de haber avistado la nao y el arribo del conquistador. La música, funciona a su vez como conector de las escenas que son sinfónicamente acompañadas y realzadas con melodías que matizan los acontecimientos con sonidos in crescendo que ayudan a enaltecer las situaciones que son reflejadas en la pantalla.

El encuentro del español con lo tropical es inmediatamente irradiado de una manera muy particular. El conquistador se encuentra bloqueado por un lienzo el cual abre con sus manos y por el cual observa una galería de personajes que representan a todos los héroes patrios venezolanos que lucharon en contra de la corona española durante el la época de la emancipación. Tres hombres pasan corriendo (son las distintas razas que se fusionaron en la Venezuela de otrora), y atraviesan esta imagen representado indios, negros y blancos. Las razas aparecen halando tres largas telas izadas de distintos tonos que simbolizan los colores patrios de Venezuela: amarillo por la riqueza natural que tiene el país, azul por el extenso mar Caribe que rodea sus costas, y el rojo por la sangre derramada durante la lucha por la independencia venezolana. Seguidamente, aparece Francisco de Miranda (es el mismo Diego Rísquez quien lo

1. Véase: Isaac J. Pardo. Esta Tierra de Gracia: imagen de Venezuela en el siglo XVI. Caracas: Concejo Municipal del Distrito Federal, 1975. p. 20. 
protagoniza), precursor de la emancipación. Con un plano cercano a su rostro, Miranda aparenta estar sentado en la Carraca, ${ }^{2}$ prisión española en donde fue encarcelado y en donde falleció. Esta imagen fue tomada del cuadro pintado por Arturo Michelena. Miranda se levanta y toma un banderín con el que se aproxima a la cámara simbolizando su presencia de líder principal en la galería de personajes que se muestra en la escena, de igual manera, Miranda arroja la banderilla al suelo y regresa a su posición en el catre en el que reposa. El simbolismo con la figura de Miranda es expuesto como la imagen del héroe nacional que inició el camino a la independencia, pero que al mismo tiempo terminó en el fracaso. Seguidamente, uno a uno se presentan los protagonistas en una toma en movimiento que se acerca a los héroes patrios que permanecen estáticos simulando las imágenes patrias, las estatuas y la iconografía que es parte de la cultura nacional venezolana. La primera figura entonces en acercarse a la cámara es Simón Bolívar con la mano derecha en su espada, casi por desenvainarla, como si se tratase de una posición defensiva. Esta imagen luce como el Bolívar del año 1813, fecha en la cual fue proclamado el Libertador, y fecha en la cual muchas pinturas lo reflejan vistiendo su legendario traje de casaca roja y espigas doradas.

\section{Infancia, adolescencia y emancipación: de Simón a Libertador}

La niñez del Libertador es representada a continuación con la negra Hipólita, esclava de la familia Bolívar y Palacios que se encargó de criar a Bolívar y quien además lo amamantó. Hipólita mece a Simón y lo carga en su pecho exponiéndose simbólicamente la importancia maternal que ésta esclava tuvo en la crianza del Libertador. También, Rísquez representa rápidamente al Bolívar niño cabalgando un caballo blanco de cerámica en el que el joven Bolívar monta jovialmente observando una guacamaya colorida que permanece con él en ese instante. Rísquez además incluye el matrimonio de Bolívar con la española, María Teresa del Toro, en una escena frente a una iglesia, y a continuación, se simboliza el regreso de Bolívar con su esposa en un barco que navega con destino a Venezuela. En una escena muy breve, María Teresa y Bolívar caminan por la hacienda de San Mateo, lugar donde vivieron luego de su regreso de Madrid, ambos reciben una fruta que les da un campesino. Súbitamente, Rísquez incluye una escena melancólica que presenta la muerte de la esposa de Bolívar y éste observándola en la cama. Dicha imagen ha sido tomada de las pinturas de Tito Salas, ${ }^{3}$ artista venezolano que dedicó gran parte

2. Véase: Colección de pinturas, dibujos y estampas del siglo Xix. Caracas: Fundación Galería de Arte Nacional, 1993, p. 131.

3. Véase: Rafael Pineda, La pintura de Tito Salas. Caracas: E. Armitano, 1974. 
de su obra a la imagen del Libertador reflejándola en pinturas, frescos y en murales auspiciados por el gobierno venezolano. Cabe destacar que muchas de estas pinturas permanecen actualmente intactas en lugares como la casa natal del Libertador en el Centro de Caracas, cuyas paredes fueron decoradas por Salas exponiendo muchas de las situaciones vividas por Bolívar en sus 47 años de existencia. Estos murales han servido a muchos biopic sobre Bolívar.

Históricamente, se conoce que luego de la desaparición física de la esposa de Bolívar, el Libertador parte para Europa en medio de una conmoción emocional. En Italia, Bolívar se encuentra con Simón Rodríguez, su maestro y mentor, juntos realizan un peregrinaje en Roma. Rísquez utiliza el conocido discurso en el Monte Sacro, en el cual Bolívar y Rodríguez intercambiaron pensamientos en busca de la independencia venezolana. De esta conversación, surgió el "Discurso del Monte Sacro", ${ }^{4}$ pronunciado y fechado en la historia bolivariana un 15 de agosto de 1805. En dicha alocución, Bolívar jura no dar descanso a su brazo ni sosiego a su alma hasta derrotar a los españoles y a la impuesta opresión que ha tenido el continente latinoamericano. El simbolismo aplicado por Rísquez se resume en escenificar a Simón Bolívar alzando su brazo con fuerza. Bolívar, es entonces desplazado de la pantalla por otro Simón Bolívar que simboliza como una especie de alter ego que presenta la llegada de una nueva era en la historia de la independencia venezolana. El nuevo Libertador, que aparece de ahora en adelante, pasa a defender la patria con la espada desenfundada y erguida apuntando al cielo. Son muchos los significados que se expresan a través de las imágenes propuestas por Rísquez en muchas escenas, sin embargo, ésta escena en particular establece los parámetros de una nueva etapa que personifica el comienzo de la lucha por la emancipación de ahora en adelante.

Seguidamente, reaparecen las tres razas de la misma manera como emergen al principio del film. Un indio hala el color amarillo, un blanco el azul, y un negro el rojo. Se trata de los colores de la bandera venezolana que van subliminalmente camino a la libertad. Esta interpretación presenta además la fusión de razas y culturas ocurrida en Venezuela durante el encuentro de dos mundos. A su vez, Rísquez escenifica en una toma panorámica que muestra los personajes históricos que posan primeramente, estáticos, vestidos con trajes de gala muy típicos de la época independentista venezolana, y que posteriormente empiezan a aplaudir interpretando la celebración del acta de la declaración de la independencia venezolana. Lo que se presenta en escena es entonces una fusión entre la iconografía y la historiografía nacional a través del punto de $3-4$.

4. Léase en: Simón Bolívar, Doctrina del Libertador. Caracas, Biblioteca Ayacucho, p. 
vista cinematográfico en el cual Rísquez utiliza la cámara y distintas tomas en movimiento que invitan al espectador a formar parte de los sucesos, la escenografía y los personajes expuestos en la pantalla. Cabe destacar que Rísquez aparece en esta escena representando a Francisco de Miranda, precursor de la independencia latinoamericana. La escena es el reflejo vívido de la pintura del artista venezolano Martín Tovar y Tovar titulada: Boceto para la firma del acta de independencia venezolana.

La diversidad cultural, los linajes y la raza, son temas profundizados a continuación en una etapa de escenas que muestran la presencia de los indios y llaneros autóctonos de las tupidas zonas verdes de la gran sabana venezolana. Los héroes de la independencia son presenciados conviviendo en chozas, palafitos y trasladándose en canoas; también, aparecen tejiendo, comiendo casabe, pescando con mayas, e intercambiando ideas con negros, esclavos, indios y llaneros, sin ningún tipo de distinción social, reflejando la variedad, la unión y el lazo patriótico que acopló a los hombres venezolanos en el período de la independencia. El objetivo de Rísquez es participar la importancia que tuvo esta unión de razas en pro de la libertad y el impacto positivo que tuvo la campaña de Bolívar cuando se unió a las hordas llaneras del lancero, José Antonio Páez, quien comienza a aparecer en escena liderando a los próceres de la independencia que atraviesan las llanuras, ríos y zonas rurales típicas de la selva venezolana. El catire Páez, es representado como un llanero hábil que tiene mucha influencia entre los habitantes de la región central de Venezuela, donde las inmensas planicies y áreas verdes rodeadas por ganado vacuno, caballar, y animales de otras especies, son mostradas en escena simbolizando la unión entre las tropas bolivarianas y las hordas llaneras las cuales se juntaron para enfrentar a los españoles en el campo de batalla. La imagen de Bolívar y la figura de Páez, son presentadas en adelante como los dos líderes que toman las riendas del recorrido geográfico que se expone en el film durante cabalgatas y aventuras típicas tradicionales de los llanos Venezolanos.

Una escena muy particular alude a la batalla que se avecina entre Venezuela y España. Se trata de un gallo blanco que aparece frente a la cámara y que posa delante de una de las torres de observación de una fortaleza o castillo construido por los españoles. La bandera de Venezuela aparece en el medio, participando la disputa que existe entre la corona española y los bolivarianos. El gallo, es tradicionalmente utilizado en los llanos venezolanos como símbolo de pelea, como parte de una tradición que mezcla el azar, la batalla, la muerte, la brujería y el espiritismo. Rísquez utiliza esta simbología para representar entonces lo que a continuación es escenificado con distintas etapas que exponen a los próceres venezolanos participando en múltiples situaciones 
folclóricas en lugares muy particulares de Venezuela. La pelea de dos gallos es por ejemplo, una de estas particulares circunstancias que se muestran en el film cuando un héroe patrio aúpa y apuesta por un gallo que a pico y espuelas ataca a su oponente rodeado por llaneros, indios y patriotas bolivarianos. Otra conexión cultural y folklórica que utiliza Rísquez, es la lectura del tabaco, cuya simbología es transmitida a través de Pedro Camejo, mejor conocido por la historiografía como el negro primero. Esta interesante escena participa el destino que le espera a Venezuela. Camejo aparece vestido de rojo tal cual como lo representa la iconografía venezolana en manos de Martín Tovar y Tovar, en los lienzos del salón elíptico en el Congreso venezolano. Curiosamente, el negro primero es quien presagia los eventos de la venidera independencia cuando fuma, escupe y sacude su cuerpo expresando los acontecimientos que el ritual del tabaco le transmite.

El negro Camejo reaparece en un desierto. Se trata de los médanos de Coro, zona árida ubicada en el Estado Falcón, lugar donde se encuentra además la península de Paraguaná, área geográfica e histórica por donde desembarcó Francisco de Miranda en busca de la independencia en la conocida expedición de 1806 que arribó a las playas de la Vela de Coro. ${ }^{5}$ Rísquez fusiona iconografía con historiografía y traslada las imágenes de los libertadores al desierto mostrando una escena compleja. Pedro Camejo, el negro primero, en medio de un ritual en el que fuma tabaco, corta con un machete una sandía. Son siete trozos los que reparte, y son estos siete pedazos los que simbolizan la separación de las siete provincias venezolanas: Caracas, Cumaná, Barcelona, Barinas, Margarita, Mérida y Trujillo. El general José Antonio Páez, reaparece y lidera la tropa patriótica rodeada de bueyes cornudos, toros, vacas y caballos, ganado típico del Arauca. Rísquez recrea la Batalla de las Queseras del Medio (ocurrida el 2 de abril de 1819), a través de imágenes simbólicas que muestran a los llaneros arreando ganado y coleando toros que son halados y tumbados representado uno de los enfrentamientos más importantes pilotados por Páez. El triunfo se observa a través de la imagen del general Páez cuando cabalga sin camisa y con su lanza en mano celebrando haber vencido a Pablo Morillo, general español a cargo de las tropas que enfrentaron a los llaneros. Retrospectivamente, el film retorna a la galería de los héroes patrios que es presentada al comienzo. La imagen de Simón Bolívar es mostrada con la espada desenvainada elevada con la mano derecha. El Libertador camina hacia la cámara y los demás próceres lo siguen. Atrás quedan Manuela Sáenz, Francisco de Miranda y el conquistador español, éste, arroja su espada y su yelmo y se cubre

5. Al respecto léase: Eduardo Cobos. Desembarco de Francisco de Miranda en la Vela de Coro. Caracas: Banco Central de Venezuela, 2010. 
el rostro con un largo velo negro para empezar a perseguir a los libertadores en una nueva etapa. El conquistador atraviesa la cámara y la pantalla es cubierta por el velo negro que cierra la escena simulando su desaparición o muerte.

Con la bandera izada, los llaneros y patriotas atraviesan las sabanas venezolanas. Montando caballos a pelo, Bolívar lidera la ruta que él y sus generales siguen para atravesar vastas distancias que históricamente fueron las rutas recorridas por el Libertador en sus campañas patrióticas. Cabe destacar que durante este recorrido, los libertadores conviven en el llano, exploran la selva, los ríos, la flora y la fauna típica de Venezuela. Comparten juntos una comida sentados en una mesa como si se tratase de una referencia al cuadro de la última cena de Da Vinci, pero desde un punto de vista tropical y llanero pues los libertadores comen arepas en vez de pan y beben agua de una tapara, en vez de vino del cáliz. Toda esta etapa en los llanos, presenta como fue la formación de los generales del Libertador. Sus distintas etapas de formación geopolítica, las estrategias que utilizaron para sobrevivir en las sabanas, en territorios áridos, en distintas zonas geográficas que tuvieron una gran huella en la emancipación venezolana ya que cada una de las batallas ganadas tuvo lugar en distintas partes del país. Rísquez utiliza además lugares históricos que hoy día son patrimonio de la cultura nacional, y a su vez, Rísquez utiliza constantemente la simbología patria y sus colores para matizar los paisajes que presenta a través de la cámara.

Una nueva escena presenta otra imagen muy particular de la iconografía bolivariana. Se trata del cruce de los Andes. Un guía barbudo, vestido de blanco y junto a su también nevado lanudo mucuchíes (perro típico de las montañas andinas), aparece en pantalla con la bandera de Venezuela atada a un bastón o palo largo. El fondo de la escena es el Páramo de Pisba, zona fría y montañosa por la cual Bolívar y su ejército atravesaron para cortar camino y sorprender al ejército español en la campaña de la Batalla de Boyacá en 1819. El contraste y la fusión de las imágenes propuestas por Rísquez, simbolizan lo que otrora hicieron las pinturas de Tito de Salas, la diferencia, es que Rísquez le da vida a estos lienzos y a la iconografía, reviviendo visualmente los momentos históricos más importantes de la vida de Simón Bolívar. Estos momentos son presentados por Rísquez al mostrar el peregrinaje que vivió el Libertador, sus generales y séquito que lo siguieron durante el cruce de los Andes. Interesantemente, Rísquez detalla tanto el paisaje como el trasfondo narrado por la historiografía nacional: frío, agotamiento, penuria, incertidumbre, vértigo y el logro alcanzado al culminar la hazaña de atravesar el páramo de Pisba. Lo héroes patrios logran la proeza y descienden la empinada colina siguiendo al guía y a la bandera venezolana. Logran el objetivo y comparten nuevamente 
una comida juntos en una mesa simbolizando la unión y la preparación para el enfrentamiento que se avecina.

Simón Bolívar dicta un discurso a uno de sus edecanes y éstos se preparan para salir juntos al campo de batalla. A continuación se presentan escenas que emulan la batalla de Carabobo (utilizando imágenes de los cuadros de Martín Tovar y Tovar), enfrentamiento que le dio la independencia definitiva a Venezuela. En Carabobo, el 24 de junio de 1821, los patriotas venezolanos se enfrentaron a las tropas del español, Miguel de la Torre. La batalla campal presentada por Rísquez expone un enfrentamiento entre los llaneros y militares que acompañaron a Bolívar, contra los españoles que son representados vestidos de mantos negros. Agua, fuego y tierra son también parte de la escena en la que la imagen de Bolívar lidera junto con el general Páez, una de las batallas más importantes de la historia venezolana. La simbología utilizada por Rísquez en esta etapa del film propone detalles muy singulares como la presencia de los españoles a través de verdugos que sacrifican una vaca viva y que encienden fuego en el campo de batalla. Uno de los verdugos extermina a varios llaneros y entre espadas, palos y lanzas todos se enfrentan alrededor de la llamarada de fuego y el humo del pasto quemado que con trucos de cámara invitan al espectador a formar parte del enfrentamiento entre Venezuela y España. Rísquez mezcla también sucesos de la historiografía filmando escenas que muestran a los protagonistas y a sus particularidades: Bolívar en el centro de la batalla con su caballo blanco y su espada desenvainada, además, un momento muy importante de la historiografía venezolana protagonizado por el general José Antonio Páez, hecho conocido como el "vuelvan carajo", grito furioso que según la historia vociferó Páez al regresar en contraataque con su lanza exterminando los últimos españoles que quedaban en el campo de batalla. La muerte del negro Camejo, el triunfo de los bolivarianos y la desolación y destrucción en el campo de Carabobo, se observan con interesantes detalles difíciles de descifrar si no se conoce el trasfondo del hecho histórico que hay detrás de esas imágenes. En teoría, el juego visual que presenta Rísquez, es sin duda alguna una composición de ideas que se interconectan con eventos muy particulares de la historia nacional venezolana, el arte pictórica, y la historia y literatura típica del movimiento independentista ocurrido en territorio de Venezuela.

\section{Bolívar y Manuela Sáenz}

El triunfo y la gloria del Libertador luego de lograr la independencia en el campo de batalla, son representados en escena con un instante muy particular. Se trata del momento en el que Simón Bolívar observa por primera vez a 
Manuela Sáenz, su última amante que lo acompañó durante los años finales de sus campañas más importantes. Rísquez, realiza un salto histórico al trasladar a Bolívar a Quito el 22 de junio de 1822, fecha en la que Bolívar conoce a Manuela durante la llegada triunfal del Libertador en tierras ecuatorianas. La escena en la que Bolívar y Manuela se encuentran por primera vez (Bolívar en su caballo blanco, Manuela asomada en un balcón), presenta las mismas características que la historia narra sobre dicho primer encuentro. ${ }^{6}$ Manuela le arroja a Bolívar un ramo de flores y se observan fijamente en medio de la conmoción y el festejo que ocurre entre ambos. Inmediatamente, se observan esclavos vestidos de blanco bailando al ritmo de los tambores. Este tipo de baile erótico es característico de los territorios costeños mayormente poblado por habitantes negros que al ritmo de la percusión y sonidos realizados con conchas marinas como el botuto (caracol), reflejan no solamente la celebración de la emancipación alcanzada por Bolívar, sino que además expresan metafóricamente, la libertad de los esclavos y la fusión de la razas.

Manuela Sáenz, reaparece en escena observándose frente a un espejo al pintarse unos bigotes que le dan un aspecto masculino muy peculiar. La imagen varonil de Manuela expuesta por Rísquez, forma parte de la historiografía que cuenta que Manuela Sáenz se vestía de general y se hacía pasar por hombre para comandar las tropas de Bolívar y hasta para impartir órdenes a los edecanes del Libertador. Manuela fue Ministro de Guerra del Libertador, y es por esto que se refleja dicha imagen de la generala Manuela. ${ }^{7}$ Rísquez no solamente propone esta figura en este film, también, la desarrolla a cabalidad en otra de sus películas titulada: Manuela Sáenz, la Libertadora del Libertador (2000). Este film presenta la figura de Sáenz y la imagen de Bolívar desde un punto de vista erótico y melancólico en el cual la presencia de Manuela es expuesta en varias ocasiones vestida de traje de gala militar típico de la época independentista de la Gran Colombia. Un ejemplo clave para comprender lo que sucede con la presencia masculina de Manuela, es la dualidad de su relación con Bolívar, amante y a su vez crítica de la situación que rodea al Libertador. Esta situación es expuesta también por Rísquez en su Sinfonía tropikal una vez que Manuela y el Libertador se encuentran cabalgando sus caballos en un camino rural. Manuela viste un traje de libertadora y lleva un fusil en la espalda; también, Manuela arriba al encuentro con Bolívar con una de sus esclavas que también galopa junto a ellos.

6. Véase: David Bushnell, Simón Bolívar: Hombre de Caracas, Proyecto de América: una biografía. Buenos Aires: Editorial Biblos, 2002, p.118.

7. Un relato muy interesante con respecto a la llegada de Manuela al cuartel militar de Quito vestida de traje militar después de la batalla de Ayacucho aparece en: Verdesoto de Romo Dávila. R, y Manuela Sáenz. Manuela Sáenz. Biografía Novelada. 2 tom. Quito, 1963, p.40. 
Bolívar y Manuela empiezan su romance al beber varios sorbos de unas copas de plata las cuales sostienen mientras se observan fijamente. La relación amorosa de Bolívar y la Libertadora del Libertador (término utilizado por el mismo Libertador para referirse a Manuela luego de que ésta lo rescatara del atentado septembrino), se presencia cuando ambos reposan en una hamaca. El cabello largo de Manuela cuelga y Bolívar repentinamente parte de la escena erótica dejando a Manuela con los brazos extendidos. El significado de esta escena es la partida del Libertador a la guerra. La relación entre Manuela y Bolívar siempre fue tumultuosa debido a las obligaciones militares del Libertador. Rísquez refleja dichas etapas al colocar a Manuela en distintas escenas que complementan muchos de los sucesos más interesantes que ambos vivieron y que se hicieron populares a través de cartas originales escritas por Bolívar. También, se empieza a observar una secuencia de imágenes sugestivas que resaltan momentos realmente particulares de la historiografía bolivariana. Bolívar deja a Manuela y aparece en escena en la cúspide de una montaña en donde aparece un viejo barbudo con un bastón muy largo vestido de blanco detrás del Libertador. La reflexión de esta escena tiene que ver con el famosos discurso de Bolívar conocido como: "Mi delirio sobre el Chimborazo" en 1822. Con respecto al delirio sobre el volcán ecuatoriano:

No se conoce el documento autógrafo original del texto poético de "Mi delirio sobre el Chimborazo", ni hay información fidedigna acerca de la fecha y lugar de composición. El Delirio se estima como una de las páginas más hermosas de Bolívar. En la mayor parte de estudios sobre el estilo literario del Libertador se menciona este texto porque realmente es obra de excepción en los escritos de Bolívar. En ella, Bolívar animado por su propia acción se detiene a animar la obra hecha. En "Mi delirio sobre el Chimborazo" (1822) se supone a sí mismo desde la cima del volcán ecuatoriano en la visión real de América por el Dios de Colombia. ${ }^{8}$

Rísquez representa en el Chimborazo la dualidad del Bolívar pensador y el protagónico que rememora desde su lecho de muerte los sucesos más importantes de su vida, su obra y su imagen. De hecho en el fragmento de la escena en la cima del volcán ecuatoriano, se observa como un Libertador abandona el cuadro por el lado izquierdo de la pantalla, y otro Libertador ingresa por el lado derecho. El simbolismo refleja el doble significado del discurso del Chimborazo, cuyo contenido está impregnado de alucinaciones y presagios supuestamente escritos por el Libertador.

8. Pedro Grases, y Arturo Uslar Pietri. Escritos selectos. Caracas, Venezuela: Biblioteca Ayacucho, 1989, pp. 190-191. 


\section{La agonía del Libertador}

En adelante, son muchas las escenas que empiezan a mostrar los momentos finales de la vida del Libertador, en especial, los momentos más difíciles de su carrera política. En principio, esta etapa del fin que propone Rísquez es simbolizada por medio de imágenes nutridas con detalles iconográficos, historiográficos, y hasta epistolares. Como ejemplo, Bolívar es trasladado en la selva encima de una camilla de bambúes cargada por indios, como si se tratase de una ceremonia faraónica. El hecho refleja la etapa dictatorial propuesta por el Libertador en la Constitución de Bolivia del año 1828, en la que Bolívar propone un mandato único en su poder y de carácter hereditario al estilo de una monarquía. De igual forma, Rísquez simboliza esta transición mostrando en pantalla a Bolívar nuevamente trasladado, esta vez por esclavos negros, en frente del mar Caribe, esta otra imagen presenta un gran detalle, Bolívar lleva su mano derecha dentro de su uniforme de gala emulando la conocida pose de Napoleón Bonaparte. Rísquez hace la semejanza entre estas dos figuras porque Bolívar fue en ocasiones considerado el Napoleón de la América del Sur, y durante los últimas años de la vida de Bolívar, su prestigio político fue profundamente reprochado por muchos de sus seguidores que lo tildaron de dictador. Rísquez también utiliza esta etapa para desprender a Bolívar de la idea dictatorial cuando nuevamente la presencia dual de dos Bolívares es puesta en escena reflejando el momento en que Bolívar abandonó la idea monárquica que propuso en la Constitución de Bolivia. En escena, primero aparece el Libertador monárquico, esta vez portando un sombrero napoleónico, éste Bolívar, es trasladado parsimoniosamente por sus generales; segundo, aparece el otro Bolívar (alter ego), negando su aceptación por el Libertador dictatorial que es abandonado por el otro. La dualidad de Bolívar es contrapuesta y ambos se enfrentan a posteriori.

\section{Bolívar el ícono}

Rísquez presenta un duelo entre las dos imágenes de su Bolívar. A espadas, se enfrentan ambos Bolívares junto a sus caballos en frente del mar Caribe. La escena, es interferida por una imagen muy particular que junta al Bolívar glorioso del lado izquierdo de la pantalla, al Bolívar icónico pintado en un lienzo en el medio, y al Bolívar alter ego del lado derecho de la pantalla. Ambos bolívares se enfrentan y a su vez, se separan de la realidad al desaparecer uno tras otro dejando sólo al Bolívar icónico que es enfocado en un lienzo. El mensaje que plasma Rísquez refleja la posterior gloria que le quedó al Libertador a través del culto no solamente a su pensamiento, sino también a su imagen. 
Finalmente, se observan las últimas alucinaciones de Bolívar desde su lecho de muerte en la cama que pareciese levitar en frente del mar. Bolívar aparece deslumbrado y recapitula los momento más importantes de su vida política: la detención de Miranda en la prisión de la Carraca. Bolívar delira y retiene preso a Miranda; el fusilamiento del general Piar, quien traicionó a Bolívar y fue sentenciado a muerte por felonía a la patria. También, Rísquez utiliza la presencia del doctor Reverend quien se encargó de cuidar a Bolívar durante sus últimos días de vida. El doctor Reverend toma la mano de Bolívar y lo observa fijamente en frente del mar Caribe. Manuela Sáenz reaparece en la alucinación de Bolívar. Manuela encuentra una figura de Bolívar tallado en madera y que aparece colgado en una soga simulando la inminente muerte del Libertador. Manuela rescata a Bolívar y frenéticamente saca un fusil y le dispara a la cámara simulando su venganza por aquellos que traicionaron a Bolívar. El Libertador alucina, se observa la muerte del general, Antonio José de Sucre, quien recibe un balazo en la cabeza en Berruecos. El general José Antonio Páez reaparece y se representa el momento de la separación de Venezuela de Colombia con el acuerdo de la Cosiata, que se observa claramente cuando Páez rompe con sus manos la bandera venezolana. Simón Bolívar escribió en una carta dirigida al presidente de Ecuador, Juan José Flores, "he arado en el mar", y esta frase Rísquez la representa con el Libertador halando una pesada rama que traza una línea en la arena y que es borrada por el mar, simbolizando una de las frases más importantes del pensamiento bolivariano. Las tres razas vuelven a aparecer halando los colores de la bandera y Manuela Sáenz corre junto con ellos. La muerte de Bolívar llega y fallece contemplando la grandeza del mar Caribe y el trópico venezolano. Al final, un gran trozo de hielo se va derritiendo lentamente hasta descongelarse y romperse en fragmentos, quedando así, la incógnita de un final indescifrable. 
Imágenes originales de Bolívar sinfonía tropikal (1980) del archivo personal de Diego Rísquez

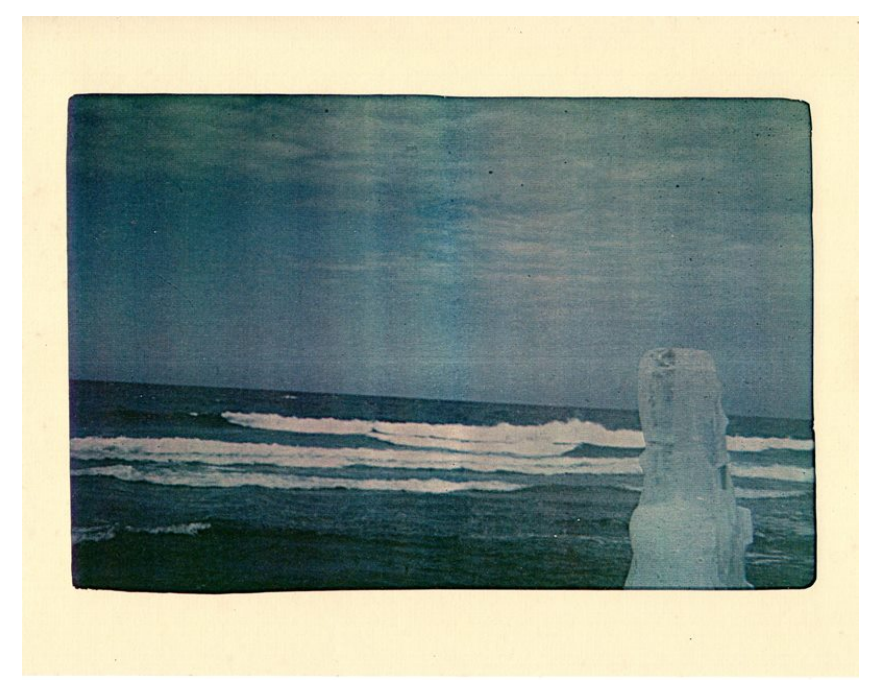

1. El busto del Libertador tallado en hielo para la escena final del film en la que simbólicamente Bolívar se desvanece en el tiempo frente al mar Caribe.

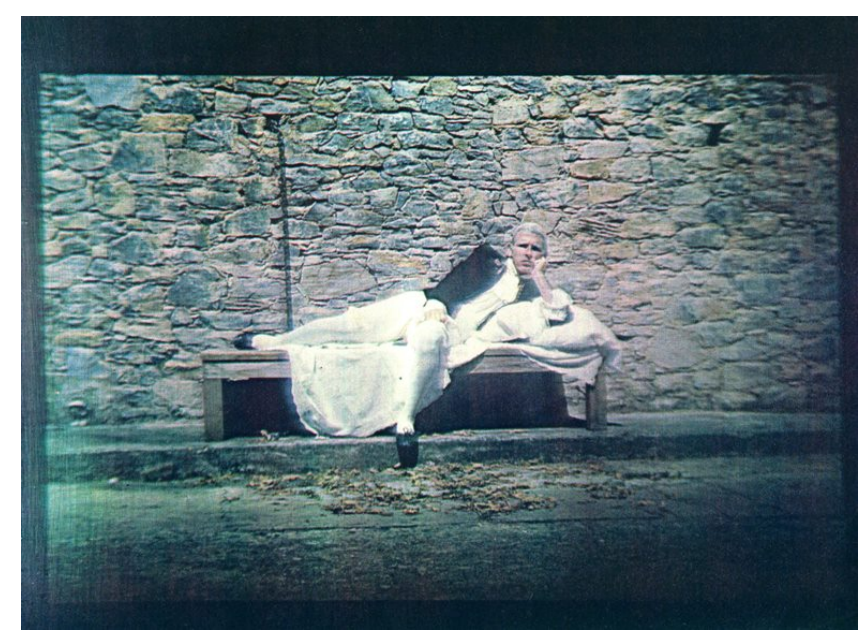

2. Diego Rísquez como Francisco de Miranda emulando el cuadro de Arturo Michelena titulado: Miranda en la Carraca. 


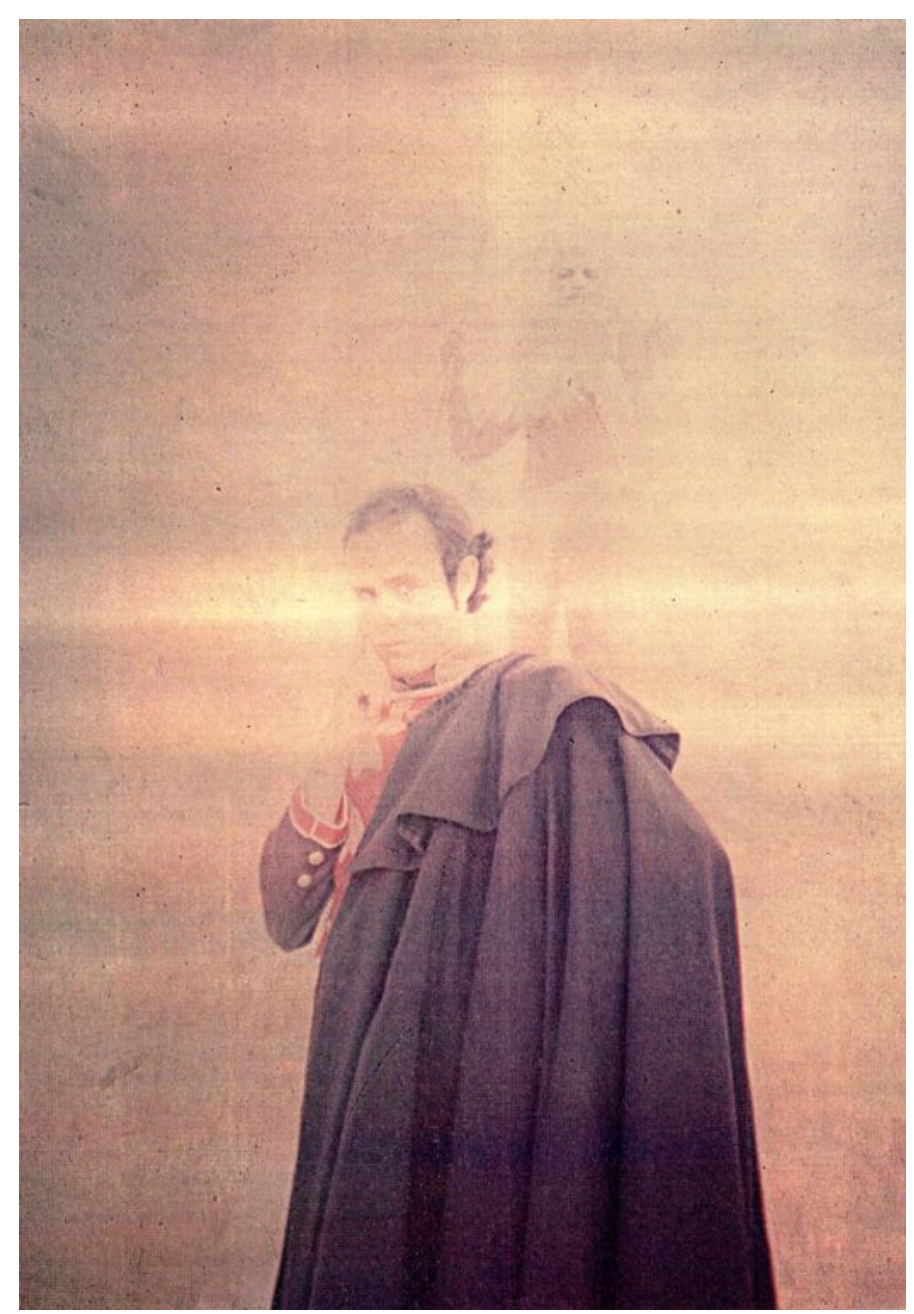

3. Escena que re-imagina la pintura de Tito Salas: "Mi Delirio en el Chimborazo". Bolívar acompañado por el anciano que representa el tiempo. 
La deconstrucción de las imágenes del Libertador en: Bolívar sinfonía tropikal (1980), de Diego Rísquez

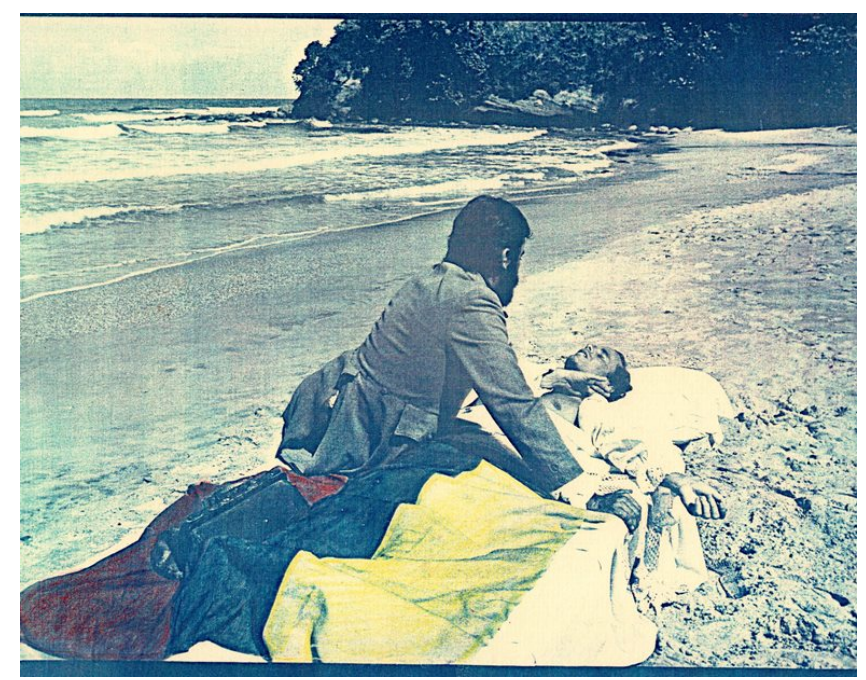

4. Bolívar alucinando rememora los eventos más importantes de su vida acompañado por el Dr. Reverend

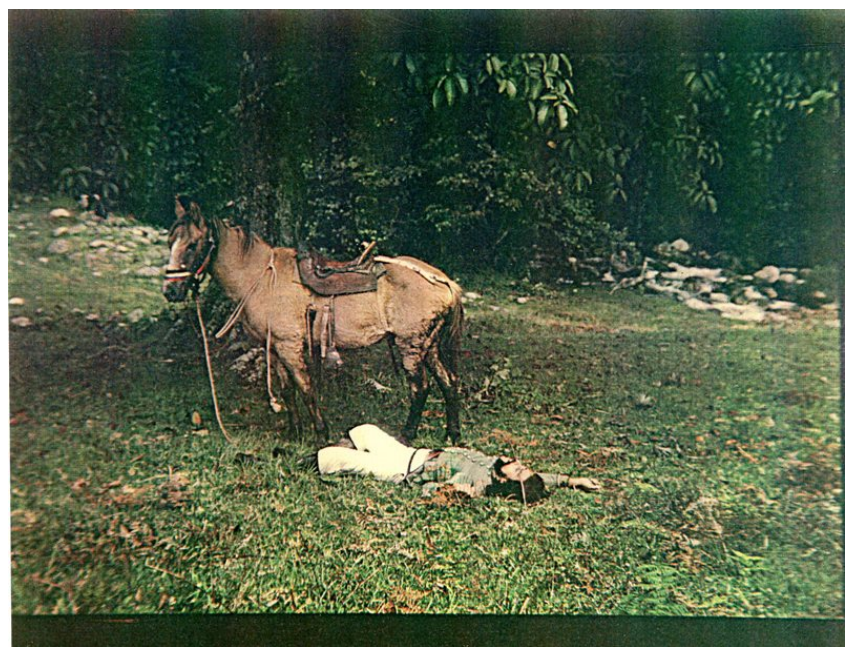

5. Escena que refleja el asesinato del general, Antonio José de Sucre, basada en la pintura de Arturo Michelena titulada: "Asesinato de Sucre en Berruecos"(1895). 


\section{Referencias bibliográficas}

Bolívar, S. \& Pérez, V. M. (2009). Doctrina del Libertador. Caracas, Venezuela: Fundación Biblioteca Ayacucho.

Bushnell, David. (2004). Simón Bolívar. Hombre de Caracas, proyecto de América. Una biografía. Buenos Aires: Editorial Biblos. (2002) Universitat de Barcelona.

Cobos, E. (2010). Desembarco de Francisco de Miranda en La Vela de Coro. Caracas: Banco Central de Venezuela.

Galería de Arte Nacional (Venezuela). (1993). Colección de pinturas, dibujos y estampas del siglo XIX: : [exposición, abril-junio 1993]. Caracas: Fundación Galería de Arte Nacional.

Grases, P. \& Uslar, P. A. (1989). Escritos selectos. Caracas, Venezuela: Biblioteca Ayacucho.

Pardo, I. J. (1975). Esta tierra de gracia: Imagen de Venezuela en el siglo XVI. Caracas: Concejo Municipal del Distrito Federal.

Pineda, R. (1974). La pintura de Tito Salas. Caracas: E. Armitano.

Verdesoto de Romo Dávila, R. \& Sáenz, M. (1963). Manuela Sáenz. Biografía novelada. 2 tom. Quito. 